\title{
Duodenorenal Fistula as a Complication of Radiofrequency Ablation of Hepatic Metastasis of Renal Cell Carcinoma
}

\section{Renal Hücreli Karsinomun Karaciğer Metastazında Radyofrekans Ablasyonun Komplikasyonu Olarak Gelişen Duodenorenal Fistül}

\author{
Arman Erkan', Coşkun Özer', Ahmet Bülent Doğrul', Haluk Özen², Okan Akhan³, Osman Abbasoğlu' \\ ${ }^{1}$ Hacettepe University Faculty of Medicine, Department of General Surgery, Ankara, Turkiye \\ ${ }^{2}$ Hacettepe University Faculty of Medicine, Department of Urology, Ankara, Turkiye \\ ${ }^{3}$ Hacettepe University Faculty of Medicine, Department of Radiology, Ankara, Turkiye
}

\begin{abstract}
Duodenorenal fistula is a rare condition. The right kidney and the second part of the duodenum are in close anatomic proximity. Although unusual, fistulae can occur between these two anatomic structures. We report a patient who presented with duodenorenal fistula after radiofrequency ablation for renal cell carcinoma and its hepatic metastasis.

Keywords: Renal cell carcinoma, radiofrequency ablation, hepatic metastasis, duodenorenal fistula
\end{abstract}

Öz

Duodenorenal fistül nadir görülen bir durumdur. Sağ böbrek ve duodenumun ikinci kısmı anatomik olarak yakın yerleşimlidir. Sık olmasa da bu iki anatomik yapı arasından fistül gelişebilir. Bu çalışmada, renal hücreli karsinom ve karaciğer metastazı nedeniyle radyofrekans ablasyon uygulaması sonrası duodenorenal fistül gelişen bir hasta bildirilmektedir.

Anahtar Kelimeler: Renal hücreli karsinom, radyofrekans ablasyon, karaciğer metastazı, duodenorenal fistül

\section{Introduction}

Fistulous connection between the duodenum and the kidney is a rare pathologic event. Duodenorenal fistula develops mostly as a result of renal inflammation, however, tumor and interventional procedures have also been reported to cause duodenorenal fistula (1). Percutaneous radiofrequency ablation (RFA) is a common procedure used to treat various tumors including hepatic metastases and renal tumors. Several complications can be seen after RFA, such as bleeding, infectious complications and injury to the surrounding tissue (2). We report a patient in whom a duodenorenal fistula developed after RFA for renal cell carcinoma (RCC) and its hepatic metastasis. de Arruda et al. (3) reported the only case of a duodenorenal fistula after renal RFA for RCC, however, to the best of our knowledge, this is the first report of a duodenorenal fistula after syncronous hepatic and renal RFA for RCC and its metastatic lesion.

\section{Case Presentation}

Our patient is a 56-year-old man who underwent partial nephrectomy for RCC three years ago. Postoperatively, the patient received interferon-alpha for RCC for one year. During the follow-up, a new $1.2 \mathrm{~cm} \mathrm{RCC}$ in the remnant kidney and a $2.2 \mathrm{~cm}$ hepatic metastasis in segment 6 were discovered. He was treated by ultrasound-guided RFA for both kidney and the liver along the same tract. A renal abscess developed one month after the RFA procedure and it was successfully treated by ultrasound-guided catheterization and drainage.

Correspondence: Ahmet Bülent Doğrul MD, Hacettepe University Faculty of Medicine, Department of General Surgery, Ankara, Turkiye Phone: +90 3123051676 E-mail: adogrul@yahoo.com

Received: 01.12.2015 Accepted: 14.06.2016

Cite this article as: Erkan A, Özer C, Doğrul AB, Özen H, Akhan O, Abbasoğlu O. Duodenorenal Fistula as a Complication of Radiofrequency Ablation of Hepatic Metastasis of Renal Cell Carcinoma. J Urol Surg 2017;4:85-87.

๑Copyright 2017 by the Association of Urological Surgery / Journal of Urological Surgery published by Galenos Publishing House. 
Three months after RFA (2 months after renal abscess), the patient presented with epigastric pain and recurrent urinary tract infection due to resistant Escherichia coli. He had been hospitalized 3 times for urinary tract infection before being admitted to our hospital. He reported normal bowel habits and no previous urinary symptom.

On physical examination, his abdomen was non-tender. His blood pressure was 125/85 $\mathrm{mmHg}$ and pulse was 92 beats/ minute.

His hemoglobin level was $13.2 \mathrm{~g} / \mathrm{dL}$, white blood cells (WBCs) and renal functions were initially normal. After presentation, WBC count was $16.000 / \mathrm{mm}^{3}$. Abdominal X-ray did not show any pathology. Preoperative abdominal computed tomography (CT) revealed free gas in the partial nephrectomy zone, which was consistent with duodenorenal fistula (Figure 1).

Laparotomy was performed; dense adhesions were present between the liver, right kidney and duodenum. A duodenorenal fistula was identified, right nephrectomy was performed and the defect on the duodenal wall was repaired primarily (Figure 2).

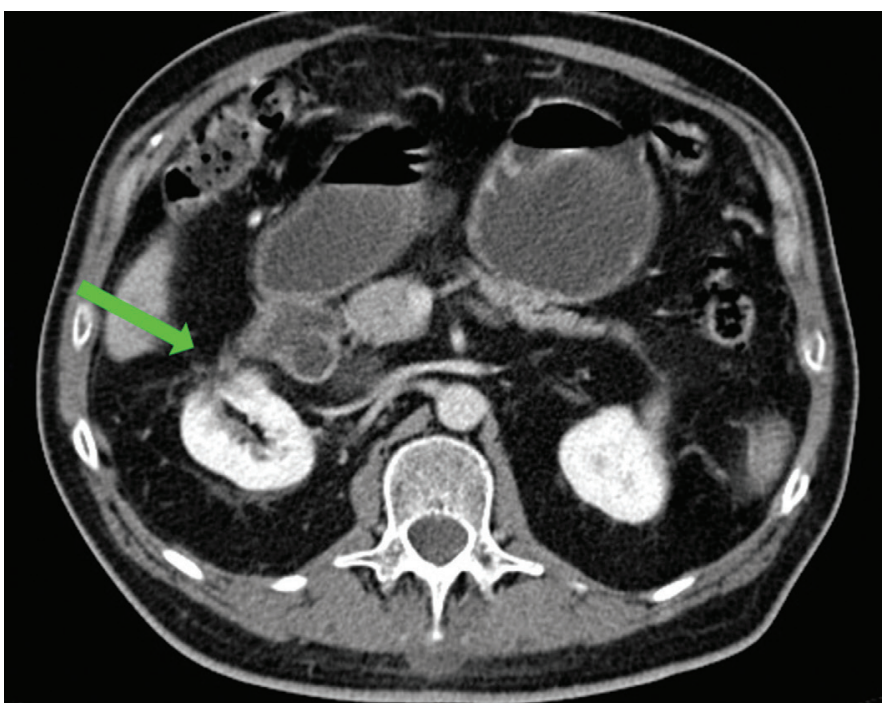

Figure 1. Contrast-enhanced abdominal computed tomography shows the fistula between duodenal bulbus wall and right kidney

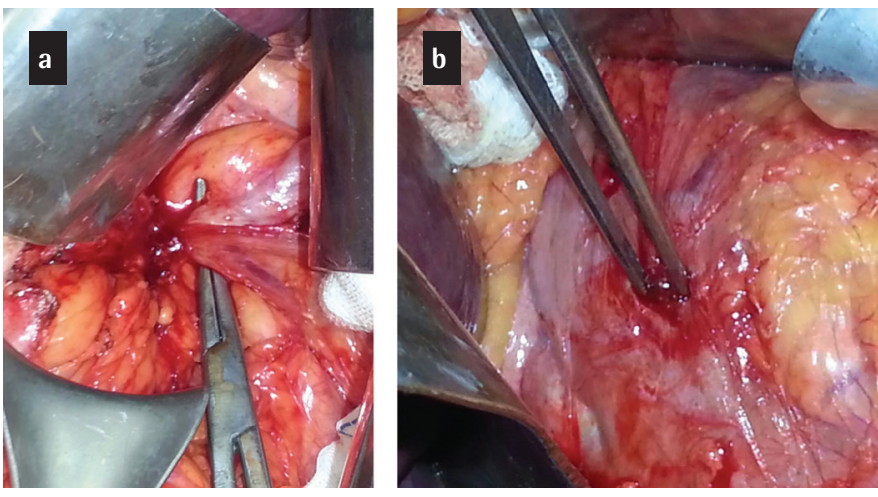

Figure 2. a) Duodenorenal fistula, b) Duodenal part of fistula
Pathological examination confirmed not only the presence of duodenorenal fistula and chronic inflammation process but also recurrent RCC in another site of the right kidney, which was apart from the RFA and fistula site.

\section{Discussion}

Reno-alimentary fistulae are rare conditions. The most prevalent form is colorenal fistula followed by duodenorenal fistula (4). They mostly occur on the right side as a result of anatomic proximity, although a few cases of fistulae from left kidney to the third portion of duodenum have been reported (5).

Duodenorenal fistula has been reported since 1839 and they can be classified as traumatic and spontaneous (6). The most common causes of spontaneous duodenorenal fistula are primary diseases of the kidney, usually chronic perinephrotic inflammation; renal calculi and obstruction $(1,5)$. Resulting perinephritis and possible abscess can lead to erosion of the renal pelvis and duodenum and the fistula occurs. On the other hand, traumatic fistulae result from direct perforation of the renal pelvis by a foreign body (ureteral catheter, nephrostomy tube, swallowed hairpin or toothpick, bullet) or severe blunt trauma (7). Primary gastrointestinal disorders are rare causes of duodenorenal fistulae $(4,8)$. Only one case has been reported after RFA of the renal tumor (3).

Patients with duodenorenal fistula may present with a variety of gastrointestinal and urinary symptoms, including right upper quadrant tenderness, flank pain, nausea, diarrhea and recurrent urinary tract infections (9). In our case, the patient had only non-specific epigastric pain, whereas he had been hospitalized three times for urinary tract infection.

Historically, retrograde or intravenous pyelography had been the radiologic procedure of choice for the diagnosis of renoalimentary fistula but CT urography which is widely available today is a much more rapid and easier alternative.

Radiofrequency ablation relies on a needle electrode to deliver an alternating current via the tip of an electrode into the surrounding tissue, leading to alternating movement of ions along the direction of the current and the friction results in tissue heating. As the temperature rises above $60{ }^{\circ} \mathrm{C}$, cell death begins, resulting in a region of necrosis surrounding the electrode (10).

Duodenal injury, gastric injury and colon perforation have been reported after RFA for hepatic lesions (2). Our patient had undergone RFA for both recurrent RCC on the remnant kidney and hepatic metastasis of RCC. Both procedures were carried out at the same session and along the same tract. Duodenorenal fistula may develop after chronic perinephrotic inflammation and abscess, however, this process usually takes years (11). What 
was critical with our patient was that two RFA procedures were combined and the fistula was diagnosed only three months later. Prolonged exposure to high temperature due to combined procedures could be the underlying mechanism. Using different tracts for subsequent RFA procedures may help lower the incidence of such complications.

Nephrectomy and primary repair of the duodenum are still treatment of choice for patients with a poorly functioning kidney (due to renal infection) or any suspicion of malignancy, however, every attempt to preserve the kidney should be made for traumatic fistulae (7).

In conclusion, duodenorenal fistula is a rare entity, mostly due to chronic renal infection. Less frequently, trauma or malignancy may result in pathologic communication between the duodenum and kidney. RFA, a prevalent technique used for tumor ablation can result in thermal and infectious complications within the adjacent tissues and organs. This is a rare case of a duodenorenal fistula complicating hepatic and renal RFA for metastatic RCC. Surgical intervention is necessary in patients with a history of malignancy.

\section{Ethics}

Informed Consent: Consent form was filled out by the participant.

Peer-review: External and internal peer-reviewed.

\section{Authorship Contributions}

Surgical and Medical Practices: H.Ö., O.A., A.B.D., O.A., Concept: O.A., A.B.D., O.A., Design: A.B.D., H.Ö., A.E., C.Ö., Data Collection and Processing: A.E., C.Ö., O.A., Analysis or Interpretation: O.A., O.A., A.B.D., H.Ö., Literature Search: A.B.D., A.E., C.Ö., Writing: A.B.D., A.E., C.Ö.
Conflict of Interest: No conflict of interest was declared by the authors.

Financial Disclosure: The authors declared that this study received no financial support.

\section{References}

1. Atalla MA, Tajkarimi K, Vinh D, Guarnaccia SP. Pyeloduodenal fistula. J Urol 2009;181:2733-2734.

2. Howenstein MJ, Sato KT. Complications of radiofrequency ablation of hepatic, pulmonary, and renal neoplasms. Semin Intervent Radiol 2010;27:285-295.

3. de Arruda HO, Goldman S, Andreoni C, Maia RS, Szejnfeld J, Ortiz V. Renoduodenal fistula after renal tumor ablation with radiofrequency. Surg Laparosc Endosc Percutan Tech 2006;16:342-343.

4. Arthur GW, Morris DG. Reno-alimentary fistulae. Br J Surg 1966;53:396402.

5. Desmond JM, Evans SE, Couch A, Morewood DJ. Pyeloduodenal fistulae. A report of two cases and review of the literature. Clin Radiol 1989;40:267270.

6. McDougal WS, Persky L. Traumatic and spontaneous pyeloduodenal fistulas. J Trauma 1972;12:665-670.

7. Fedorko $M$, Linhartová $M$, Pacik $D$, Němcová E. Pyeloduodenal fistula due to proximal ureterolithiasis and its successful conservative management. Urolithiasis 2013;41:541-544.

8. Tan SM, Teh $\mathrm{CH}$, Tan PK. Duodeno-ureteric fistula secondary to chronic duodenal ulceration. Ann Acad Med Singapore 1997;26:850-851.

9. Chen $\mathrm{CH}$, Cheng $\mathrm{HL}$, Tong $\mathrm{YC}$, Pan $\mathrm{CC}$. Spontaneous pyeloduodenal fistula: an unusual presentation in advanced renal transitional cell carcinoma. Urology 2002;60:345.

10. McGahan JP, Brock JM, Tesluk H, Gu WZ, Schneider P, Browning PD. Hepatic ablation with use of radio-frequency electrocautery in the animal model. $J$ Vasc Interv Radiol 1992;3:291-297.

11. Hui Wu J, Xu Y, Qiang $X u Z Z$, Yang $K$, Qiang Yang $S$, Shun Ma H. Severe anemia and melena caused by pyeloduodenal fistula due to renal stoneassociated squamous cell carcinoma. Pak J Med Sci 2014;30:443-445 